\title{
GAMBARAN DISIPLIN BELAJAR PESERTA DIDIK DI SMA N 1 RAMBATAN
}

\author{
Besti Nora Dwi Putri \\ Dosen STKIP PGRI Sumatera Barat \\ Email: bestinora2187@gmail.com
}

\begin{abstract}
Abstrak
Penelitian ini dilatarbelakangi oleh permasalahan siswa yang banyak mengalami masalah tentang disiplin belajar di sekolah. Banyak siswa yang tidak tuntas dalam belajar. Penelitian ini bertujuan untuk mendeskripsikan disiplin belajar siswa. Penelitian ini menggunakan metode kuantitatif jenis deskriptif. Populasi penelitian adalah siswa SMA Negeri 1 Rambatan Tahun Ajaran 2014/2015 yang berjumlah 522 orang, sampel sebanyak 208 orang, yang dipilih dengan teknik stratified random sampling. Instrumen yang digunakan adalah kuesioner. Data dianalisis dengan statistik deskriptif. Temuan penelitian memperlihatkan bahwa disiplin belajar secara umum berada pada kategori sedang. Hasil yang diperoleh dalam penelitian ini dapat dijadikan salah satu masukan bagi guru BK dan guru matapelajara dalam rangka lebih meningkatkan disiplin. Adapun upaya yang dapat dilakukan guru BK yaitu melaksanakan beberapa jenis layanan yang ada.

Kata Kunci: disiplin belajar, peserta didik
\end{abstract}

\section{PENDAHULUAN}

Sekolah sebagai lembaga pendidikan formal mempunyai visi yang mulia melalui penciptaan suasana belajar yang kondusif, untuk mengembangkan potensi-potensi siswa dalam mewujudkan tujuan pendidikan nasional. Tujuan Pendidikan Nasional dalam Undang-undang No 20 Tahun 2003 Bab 2 Pasal 3 tentang Sistem Pendidikan Nasional, yaitu pendidikan nasional berfungsi mengembangkan kemampuan dan membentuk watak serta peradaban bangsa yang bermartabat dalam rangka mencerdaskan kehidupan bangsa, bertujuan untuk berkembangnya potensi peserta didik agar menjadi manusia yang beriman dan bertaqwa kepada Tuhan Yang Maha Esa, berakhlak mulia, sehat, berilmu, cakap, kreatif, mandiri, dan menjadi warga negara yang demokratis serta bertanggung jawab.

Agar tujuan pendidikan nasional dapat terwujud, dibutuhkan upaya dari personil sekolah. Upaya yang dapat dilakukan antara lain dengan mengoptimalkan proses pembelajaran oleh guru mata pelajaran dan pelayanan dalam bimbingan 
dan konseling oleh guru BK. Proses pembelajaran diharapkan mendorong manusia untuk belajar aktif, mandiri dan memberdayakan semua potensi yang ada dalam dirinya. Salah satu cara yang dapat dilakukan adalah dengan belajar. Belajar yang dilakukan oleh manusia merupakan bagian dari hidupnya, berlangsung seumur hidup, kapan saja, dimana saja, baik di sekolah maupun di luar sekolah dalam waktu tidak dapat ditentukan sebelumnya.

Belajar pada hakikatnya adalah salah satu proses perubahan tingkah laku yang dilakukan siswa dalam usaha mengembangkan potensi. Sardiman (2012:20) menjelaskan bahwa belajar merupakan perubahan tingkah laku atau penampilan dengan serangkaian kegiatan, misalnya dengan membaca, mengamati, mendengarkan, meniru dan sebagainya. Belajar akan lebih baik, kalau siswa belajar mengalami atau melakukan tindakan-tindakan yang menunjukkan kegiatan seperti: menulis, menghafal dan mengingat. Hamzah B. Uno (2012:16) mengemukakan bahwa belajar sebagai perubahan perilaku yang terjadi setelah siswa mengikuti atau mengalami proses belajar mengajar, yaitu hasil belajar dalam bentuk penguasaan kemampuan atau keterampilan tertentu. Jadi belajar adalah perubahan yang terjadi pada siswa berdasarkan hasil latihan dan pangamatan.

Tinggi rendahnya hasil belajar siswa di kelas berkaitan dengan karakter siswa itu sendiri. Karakter siswa yang paling dominan dalam menentukan keberhasilan belajar adalah disiplin dalam belajar. Dengan disiplin siswa akan berperilaku positif sehingga dapat meningkatkan hasil belajarnya. disiplin tersebut merupakan sesuatu yang berkenaan dengan pengendalian diri seseorang terhadap bentuk-bentuk aturan yang telah ditetapkan. Akhmad Sudrajat (2008:24) menjelaskan setiap siswa dituntut dan diharapkan untuk berperilaku setuju dengan aturan dan tata tertib yang berlaku di sekolah. siswa perlu memiliki sikap disiplin belajar dengan melakukan latihan yang memperkuat dirinya sendiri untuk selalu terbiasa patuh dan mempertinggi daya kendali diri. disiplin yang timbul dari kesadarannya sendiri akan dapat lebih memacu dan tahan lama dibandingkan dengan disiplin yang timbul karena adanya pengawasan dari orang lain. 
Disiplin dapat tumbuh dan dibina melalui latihan, pendidikan atau penanaman kebiasaan yang harus dimulai sejak dalam lingkungan keluarga, mulai pada masa kanak-kanak dan terus tumbuh berkembang sehingga menjadi disiplin yang semakin kuat.

Seperti halnya disebutkan oleh Joko Sumarmo (2008:24) bahwa istilah disiplin sebagai kepatuhan dan ketaatan yang muncul karena adanya kesadaran dan dorongan dalam diri orang itu, tanpa disiplin yang baik suasana sekolah dan juga kelas menjadi kurang kondusif bagi kegiatan pembelajaran, secara positif disiplin memberi dukungan yang tenang dan tertib bagi proses pembelajaran.

\section{METODE}

Sesuai dengan tujuan penelitian, jenis penelitian ini adalah penelitian kuantitatif dengan menggunakan metode deskriptif korelasional, yaitu menggambarkan adanya variabel-variabel bebas yang diduga berkontribusi terhadap variabel terikat. Senada dengan itu, Suharsimi Arikunto (2002:64) mengemukakan bahwa penelitian deskriptif korelasional adalah metode penelitian yang dapat diartikan sebagai prosedur pemecahan masalah yang diselidiki dengan menggambarkan atau melukiskan keadaan objek penelitian pada saat sekarang berdasarkan fakta-fakta yang tampak dan sebagaimana adanya.

Adapun yang menjadi populasi dalam penelitian ini adalah siswa kelas X, XI dan kelas XII SMA Negeri 1 Rambatan yang terdaftar pada tahun ajaran 2014/2015. Teknik pengambilan sampel yang digunakan dalam penelitian ini adalah teknik Stratified Random Sampling. Menurut Riduwan (2007:58) Stratified Random Sampling adalah pengambilan sampel dari anggota populasi secara acak dan berstrata secara proposional, dilakukan sampel ini apabila populasinya heterogen (tidak sejenis). Pengambilan sampel yaitu strata pada kelas X, X1 dan XII. Teknik penarikan sampel penelitian dilakukan dengan menggunakan rumus Slovin (dalam A. Muri Yusuf, 2013:169).

Adapun instrumen penelitian yang digunakan untuk mengukur disiplin adalah dengan menggunakan angket. Angket disusun untuk mendapatkan gambaran secara lebih luas dan mendalam tentang pembahasan tersebut. Variabel ini akan dikembangkan dengan indikator-indikatornya dan kisi-kisi angket yang 
disusun terlebih dahulu oleh peneliti berdasarkan teori yang digunakan. Dalam hal ini peneliti menggunakan angket model skala Likert dengan lima kategori alternatif jawaban. Pemberian skor pada tiap-tiap alternatif jawaban dengan memperhatikan pernyataan positif dan negatif. Skor untuk tiap-tiap pernyataan.

\section{HASIL PENELITIAN DAN PEMBAHASAN}

\section{HASIL PENELITIAN}

Berdasarkan verifikasi terhadap data penelitian, seluruh data yang diperoleh dari hasil pengadministrasian terhadap siswa layak diolah yaitu sebanyak 208 data. Data penelitian ini meliputi variabel disiplin belajar. Berikut dikemukakan deskripsi data hasil penelitian. Data tersebut adalah sebagai berikut.

\section{Disiplin Belajar}

Hasil pengumpulan dan pengolahan data melalui instrumen disiplin belajar dari keseluruhan sampel (responden) berjumlah 208 siswa,dapat dilihat pada Tabel berikut ini.

Tabel. Distribusi Frekuensi dan Kategori Skor Disiplin Belajar (N=208)

\begin{tabular}{|c|l|c|c|}
\hline $\begin{array}{c}\text { Interval } \\
\text { Skor }\end{array}$ & \multicolumn{1}{|c|}{ Kategori } & $\begin{array}{c}\text { Frekuensi } \\
(\mathbf{f})\end{array}$ & $\begin{array}{c}\text { Persentase } \\
(\boldsymbol{\%})\end{array}$ \\
\hline$\geq 105$ & Sangat Tinggi (ST) & 0 & 0 \\
\hline $85-104$ & Tinggi (T) & 104 & 50 \\
\hline $65-84$ & Sedang (S) & 86 & 41,35 \\
\hline $45-64$ & Rendah (R) & 15 & 7,21 \\
\hline$\leq 44$ & Sangat Rendah (SR) & 0 & 0 \\
\hline \multicolumn{2}{|c|}{ Total } & 208 & 100 \\
\hline
\end{tabular}

Berdasarkan Tabel di atas terlihat bahwa dari keseluruhan sampel yang berjumlah 208 orang siswa, sebagian besar disiplin belajar mereka berada pada kategori tinggi (T) dengan jumlah frekuensi 104 siswa atau dapat dipersentasekan 50\%. Selanjutnya disusul pada kategori sedang (S) dengan jumlah frekuensinya 86 siswa atau dapat dipersentasekan pada 41,35\%, kemudian pada kategori rendah $(\mathrm{R})$ diperoleh jumlah frekuensi 15 siswa yang dapat dipersentasekan dengan nilai 7,21\%, sedangkan untuk kategori sangat rendah (SR) diperoleh frekuensinya nihil atau bernilai nol dari seluruh responden. 
Selanjutnya secara rinci deskripsi disiplin belajar berdasarkan indikator yang dapat dilihat pada Tabel berikut ini.

Tabel . Deskripsi Rata-rata (Mean) dan Persentase (\%) Disiplin Belajar Berdasarkan Indikator

\begin{tabular}{|c|l|c|c|c|c|c|c|c|c|}
\hline \multirow{2}{*}{ Variabel } & \multicolumn{1}{|c|}{ Indikator } & Ideal & Max & Min & Total & $\begin{array}{c}\text { Rata- } \\
\text { rata }\end{array}$ & $\begin{array}{c}\text { \% } \\
\text { Rata- } \\
\text { rata }\end{array}$ & Sd & Kategori \\
\cline { 3 - 9 } & $\begin{array}{l}\text { Mengikuti } \\
\text { pelajaran (7) }\end{array}$ & 35 & 33 & 15 & 5086 & 24,45 & 69,85 & 3,583 & $\mathrm{~T}$ \\
\cline { 2 - 10 } & Hadir di kelas (4) & 20 & 33 & 7 & 3165 & 15,22 & 76,10 & 2,399 & $\mathrm{~T}$ \\
\cline { 2 - 10 } \\
$\begin{array}{l}\text { Disiplin } \\
\text { Belajar }\end{array}$ & $\begin{array}{l}\text { Belajar di } \\
\text { perpustakaan (4) }\end{array}$ & 20 & 18 & 8 & 2806 & 13,49 & 67,45 & 1,838 & $\mathrm{~S}$ \\
\cline { 2 - 10 } \\
$\begin{array}{l}\text { Belajar di rumah } \\
\text { (5) }\end{array}$ & 25 & 24 & 6 & 3352 & 16,12 & 64,48 & 2,852 & $\mathrm{~S}$ \\
\cline { 2 - 10 } & $\begin{array}{l}\text { Pelajaran } \\
\text { tambahan (5) }\end{array}$ & 25 & 23 & 5 & 2996 & 14,40 & 57,60 & 4,086 & $\mathrm{~S}$ \\
\hline
\end{tabular}

Catatan :

$\begin{array}{ll}\text { Max } & =\text { Skor Maksimal } \\ \text { Min } & =\text { Skor Minimal } \\ \text { Sd } & =\text { Standar Deviasi } \\ \mathrm{T} & =\text { Tinggi } \\ \mathrm{S} & =\text { Sedang }\end{array}$

Berdasarkan Tabel di atas, terlihat bahwa disiplin belajar berada pada kategori sedang (S), secara keseluruhan skor tertinggi sebesar 103. Dari skor ideal yaitu 125, Skor terendah keseluruhan adalah 58, skor total 17407, ratarata skor 83,69 dengan persentase sebesar $66,95 \%$ dan standar deviasi berada pada nilai 10,85 .

Secara rinci dari analisis data tampak bahwa skor tertinggi rata-rata disiplin belajar terletak pada indikator hadir di kelas pada proses pembelajaran dengan persentase $76,10 \%$ berada pada kategori sedang (T), kemudian skor rata-rata terendah terdapat pada indikator mengikuti 
pelajaran tambahan dengan persentase $57,60 \%$ yang berada pada kategori rendah $(\mathrm{R})$.

\section{PEMBAHASAN}

Hasil analisis deskriptif menunjukkan bahwa gambaran disiplin belajar siswa secara keseluruhan berada pada kategori sedang yaitu. artinya disiplin belajar merupakan hal yang sangat penting dalam menunjang keberhasilan siswa dalam belajar sehingga perlu dilakukan upaya untuk membantu siswa dalam meningkatkan disiplin belajar yang lebih baik agar siswa mampu meningkatkan hasil belajar. Berdasarkan hasil pengolahan data persentase yang memiliki skor tertinggi dalam disiplin belajar adalah hadir di kelas pada proses pembelajaran dengan persentase $76,10 \%$.

Tulus Tu'u (2004:37) menjelaskan disiplin berperan penting dalam membentuk individu yang berciri keunggulan yaitu: (1) dengan disiplin yang muncul karena kesadaran diri, siswa akan berhasil dalam belajarnya, sebaliknya siswa yang sering melanggar peraturan pada umumnya terhambat optimalisasi potensi dan prestasinya, (2) tanpa disiplin yang baik suasana sekolah dan kelas akan menjadi kurang kondusif bagi kegiatan pembelajaran, (3) siswa yang disiplin akan terbiasa dengan norma-norma, nilai kehidupan sehingga siwa dapat menjadi individu yang tertib dan teratur (4) disiplin adalah jalan yang terbaik bagi siswa untuk sukses dalam belajar.

Hasil penelitian Avif Roy Rahman (2011) menjelaskan bahwa meningkatkan disiplin belajar kepada siswa secara langsung dapat pula meningkatkan hasil belajar siswa. Berdasarkan temuan ini, maka perlu kiranya dilakukan peningkatan disiplin belajar siswa agar dapat meningkatkan hasil belajar siswa agar lebih baik.

\section{SIMPULAN}

Berdasarkan temuan dan pembahasan hasil penelitian, maka dapat dikemukakan kesimpulan-kesimpulan sebagai berikut. Secara umum gambaran disiplin belajar siswa tergolong pada kategori sedang. Dengan persentase sebesar $66,95 \%$. Dengan demikian Hasil yang diperoleh dalam penelitian ini dapat 
dijadikan salah satu masukan bagi guru BK dan guru matapelajaran dalam rangka lebih meningkatkan disiplin, motivasi belajar dan hasil belajar siswa.

\section{REFERENSI}

A. Muri Yusuf. 2013. Metode Penelitian Kuantitatif, Kualitatif dan Penelitian Pengembangan. Padang: UNP Press.

Akhmad Sudrajat. 2009. Perkembangan Kognitif. Jakarta: Bumi Aksara.

Avif Roy Rahman. 2011. "Pengaruh Motivasi, Lingkungan dan Disiplin terhadap Prestasi Belajar Siswa pada Jurusan Teknik Audio Video SMK Negeri 3 Yogyakarta". Jurnal. Program Studi Pendidikan Teknik Elektronika. Universitas Negeri Yogyakarta.

Hamzah B. Uno. 2012. Teori Motivasi dan Pengukurannya. Jakarta: Bumi Aksara.

Prayitno. 2012. Jenis Layanan dan Kegiatan Pendukung Konseling (Pendidikan Profesi Konselor). Padang: FIP UNP.

Sardiman A. M. 2012. Interaksi dan Motivasi Belajar Mengajar. Jakarta: Raja Grafindo.

Soegeng Prijodarminto. 1993. Disiplin Kiat Menuju Sukses. Jakarta: Pradnya Paramitha.

Suharsimi Arikunto. 2002. Metodologi penelitian. Jakarta: Rineka Cipta.

Tulus Tu'u. 2004. Peran Disiplin pada Perilaku dan Prestasi Siswa. Jakarta: Grasindo.

Undang-undang Republik Indonesia Nomor 20 Tahun 2003 tentang Sistem Pendidikan Nasional. 2003. Jakarta: Sekretaris Negara Republik Indonesia. 
